\title{
片側性下顎骨関節突起骨折の予後の検討
}

\author{
石濱孝二・木村哲雄・小泉英彦* \\ 安井康順*・茶野珠里·古郷幹彦*
}

\section{Clinico-statistical study of unilateral mandibular condylar fractures}

\author{
ISHIHAMA Kohji · KIMURA Tetsuo $\cdot$ KOIZUMI Hidehiko* \\ YASUI Yasunobu* $\cdot$ CHANO Juri · KOGO Mikihiko*
}

\begin{abstract}
A statistical analysis was performed to determine factors that influence the clinical outcome of unilateral condylar fractures of the mandible. In this study, the fracture location was limited to the condylar neck and base of the condylar process. Twenty-eight patients, 18 males and 10 females, were treated at our clinic between January 1997 and December 2001. The age range was 7 to 79 years, and the average age was 32.6 years. Seventeen cases involved fractures of the condylar neck and 11 cases involved fractures of the base of the condylar process. Fifteen cases were treated conservatively by intermaxillary fixation, and 13 were treated surgically by using a titanium mini-plate or lag screw osteosynthesis system. The clinical outcome was determined according to the classification described by Kamiya 6 months after injury. The outcome was good in 21 cases, whereas 7 cases had restricted mouth-opening or joint sounds during jaw movements. This study revealed that two factors can negatively influence the clinical outcome of unilateral mandibular condylar fractures: one is the type of fracture in all cases and the other is the age of the patient at injury in cases treated conservatively.
\end{abstract}

Key words: unilateral condylar fracture (片側性関節突起骨折), surgical therapy（外科療法), conservative therapy (保存療法), clinical outcome (予後)

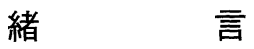

下顎骨関節突起骨折の治療については外科療法を 1,2$)$, あるいは保存療法を3－6) 推す意見それぞれに非常に多く の報告がなされており，一定の見解がえられていないのが 現状である。これまでの報告の多くは対象症例の両側, 片 側を区別していなかったり7), 保存療法だけの治療成績の 検討であったり 5)，また保存療法により良好な成績を収め ている関節突起頭部骨折を含めて検討を行っている ${ }^{2)}$. 今 回われわれは本疾患の予後に影響を与える因子を調べる目

大阪警察病院歯科口腔外科

(主任 : 木村哲雄部長)

*大阪大学大学院歯学研究科顎口腔病因病態制御学講座（口 腔外科学第一教室)

(主任 : 古郷幹彦教授)

Department of dentistry, oral and maxillofacial surgery, Osaka Police Hospital (Chief: Dr. KIMURA Tetsuo)

${ }^{*}$ Course for Integrated Oral Sciences and Stomatology, Division of Pathogenesis and Control of Oral Diseases, Osaka University, Graduated School of Dentistry (First Department of Oral Maxillofacial Surgery) (Chief: Prof. KOGO Mikihiko)

受付日：2002年 6 月17日

採択日：2003年 2 月18日
的で, 対象症例を片側性骨折で, 頸部と基底部骨折に絞り 検討を行ったので報告する。

\section{対象と方法}

対象は, 1997年 1 月から 2001 年 12 月までの 5 年間に,大 阪警察病院歯科口腔外科で治療を行い，6 か月以上の経過 観察を行いえた片側性下顎骨関節突起頸部および基底部骨 折28例である.これらの症例に対して, 受傷時より6 か月 以上経過した時点で, 神谷ら ${ }^{2)}$ の分類に従い治癒, 障害 I 〜 IVの 5 段階に予後を評価し, 以下の調査項目について検 討を行った.なお，予後を統計学的に比較するため点数化 （予後スコアー）を行い, 神谷ら ${ }^{2}$ ) の分類で治癒を予後ス コアー4 点, 障害 I を 3 点, 障害 II を 2 点, 障害 III 1 点, 障害IVは 0 点と配点した. 統計学的検定は Kruskal-Wallis の検定, Mann-WhitneyのU 検定を用い, $\mathrm{p}<0.05$ を有意 とした。なお，多重比較におけるU検定の有意水準は Bonferroni の修正を行った。

調查項目

1 ) 性別と受傷時年齢, 受傷原因, 骨折側

2 ）骨折部位と骨折様式 (久保ら ${ }^{8)}$ の分類)

3 ) 治療法 (保存療法, 外科療法) と外科療法の手術時間 
表 1 対象症例の概要

\begin{tabular}{|c|c|c|c|c|c|c|c|c|c|}
\hline case No & 性別 & 年齢 & 骨折側 & 骨折部位* & 骨折様式* & 他部位の下顠骨骨折 & 治療法 & 形態的評価** & 予後** \\
\hline 1 & 男 & 51 & 右側 & 基底部 & 位 & な & 外科 (La) & 完全治癒 & 治 癒 \\
\hline 2 & 男 & 18 & 右側 & 頸 部 & 位 & 正中骨体 & 外科 (La) & 完全治癒 & 治 癒 \\
\hline 3 & 男 & 38 & 左側 & 頸 部 & 偏位脱臼 & 右側前歯部骨体 & 存 & 変形治 癒 & 障害 III \\
\hline 4 & 女 & 7 & 右側 & 頸 部 & 偏位脱臼 & な & 存 & 不完全治癒 & 治 癒 \\
\hline 5 & 女 & 30 & 左側 & 基底部 & 転位脱臼 & 左側前歯部骨体 & 外科 (Mi) & 完全治癒 & 治 癒 \\
\hline 6 & 男 & 17 & 左側 & 基底部 & 偏 & L & 外科 (La) & 完全治癒 & 治 癒 \\
\hline 7 & 男 & 41 & 右側 & 基底部 & 亀 & な & 保 & 完全治癒 & 治 癒 \\
\hline 8 & 男 & 9 & 右側 & 頸 部 & 偏位脱臼 & な & 保 & 不完全治癒 & 治 癒 \\
\hline 9 & 女 & 39 & 右側 & 頸 部 & 偏位脱臼 & な & 存 & 変形治癒 & 治 癒 \\
\hline 10 & 女 & 7 & 右側 & 頸 部 & 転 & な & 存 & 不完全治癒 & 治 癒 \\
\hline 11 & 女 & 64 & 左側 & 頸 部 & 偏位脱臼 & な & 存 & 変形治 癒 & 障害 I \\
\hline 12 & 男 & 15 & 右側 & 頸 部 & 偏位脱臼 & な & 存 & 変 形治 瘉 & 治 癒 \\
\hline 13 & 女 & 56 & 右側 & 頸 部 & 偏 & な & 外科 (La) & 完全治癒 & 障害 II \\
\hline 14 & 女 & 57 & 左側 & 基底部 & 偏 & な & 存 & 不完全治癒 & 障害 I \\
\hline 15 & 女 & 59 & 右側 & 頸 部 & 偏 & な & 外科 $(\mathrm{Mi})$ & 完全治癒 & 治 癒 \\
\hline 16 & 女 & 16 & 左側 & 頸 部 & 偏 & な & 保 & 不完全治瘉 & 治 癒 \\
\hline 17 & 男 & 18 & 左側 & 頸 部 & 転位脱臼 & な & 外科 (La) & 完全治癒 & 障害 II \\
\hline 18 & 男 & 16 & 右側 & 基底部 & 裂 & な & 外科 (La) & 完全治癒 & 治 癒 \\
\hline 19 & 男 & 23 & 右側 & 基底部 & 偏 & な & 外科 (Mi) & 完全治癒 & 治 癒 \\
\hline 20 & 男 & 26 & 右側 & 頸 部 & 偏位脱臼 & な & 保 & 不完全治癒 & 治 癒 \\
\hline 21 & 男 & 29 & 左側 & 頸 部 & 転 & な & 外科 (Mi) & 完全治癒 & 治 瘉 \\
\hline 22 & 男 & 18 & 右側 & 頸 部 & 偏位脱臼 & 左側前歯部骨体 & 存 & 不完全治瘉 & 治 癒 \\
\hline 23 & 男 & 79 & 左側 & 頝 部 & 転位脱臼 & な & 存 & 変形治 癒 & 障害 I \\
\hline 24 & 女 & 48 & 右側 & 基底部 & 転位脱臼 & な & 外科 (Mi) & 変形治 癒 & 障害 II \\
\hline 25 & 男 & 35 & 右側 & 頸 部 & 偏 & 左側前歯部骨体 & 保 & 完全治癒 & 治 癒 \\
\hline 26 & 男 & 16 & 左側 & 基底部 & 亀 & 左側前歯部骨体 & 存 & 完全治癒 & 治 癒 \\
\hline 27 & 男 & 36 & 右側 & 基底部 & 偏 & $\begin{array}{l}\text { 右側前歯部, } \\
\text { 左側臼歯部骨体 }\end{array}$ & 外科 (Mi) & - & 治 癒 \\
\hline 28 & 男 & 45 & 左側 & 基底部 & 転 & 右側前歯部骨体 & 外科 (Mi) & - & 治 癒 \\
\hline
\end{tabular}

外科 $(\mathrm{La})$ ：ラグスクリュー固定, 外科 $(\mathrm{Mi})$ : ミニプレート固定, *久保ら ${ }^{8)}$ の分類, **神谷ら 2$)$ の分類

例では偏位骨折 (10例) と, 偏位 脱臼骨折 ( 8 例) が多かった.

骨折部位, 他部位の下顎骨骨 折の有無による予後の差は検出 されなかったが, 骨折様式の間 に有意差を認めた（KruskalWallis の検定, $p=0.0412)$. さ らに多重比較の結果, 亀裂, 偏位，転位骨折群と転位脱臼 骨折群の間に有意な差があり (Mann-Whitney の U 検定， $\mathrm{p}=0.0106)$ ，転位脱臼骨折の予 後が悪いことが分かった。

3 ) 治療法と外科療法の手術 時間

治療法については15例（54 \%)に保存療法 (シューハルト シーネを使用した顎間固定法） が，13例（46\%）に外科療法 (ミニプレート固定 7 例, ラグ スクリュー固定 6 例）がそれぞ れ選択された. 外科療法のうち， 関節突起の単独骨折で, 固定法 が異なる両者の平均手術時間を

\section{4 ) 形態的評価 (神谷 $5^{2}$ )の分類)}

\section{結}

\section{果}

神谷ら ${ }^{2)}$ の分類による予後の評価で治癒をえた症例は 21 例 $(75 \%)$ であり，障害 I は 3 例 $(11 \%)$, 障害 II は 3 例 （11\%），障害吕は1例（3％)であった（表 1$)$ ．また，障害 IVは今回の対象には認められなかった。

\section{1 ) 性別と受傷時年齢, 受傷原因, 骨折側}

男性18例 (64\%)，女性10例（36\%）で，男女比は1.8：1 であった（表 1 ）。受傷時年齢は 7 歳から 79 歳で, 平均は 32.6 歳であった. 年代別では20歳未満が11例（39\%）で最 も多かった。受傷原因では歩行時転倒が 8 例（29\%）と最 も多かった。骨折側は右側17例 (61\%), 左側11例（39\%） であった。

男女, 年齢, 受傷原因, 左右それぞれの間に統計学的な予 後の差は検出されなかった（表 2 ）.

2 ) 骨折部位と骨折様式

骨折部位は頸部17例 $(61 \%)$, 基底部11例（39\%）であっ た. 他部位の下顎骨骨折を認めた症例は 8 例 $(29 \%)$ で あった。

骨折様式については久保ら ${ }^{8)}$ の分類に従い亀裂, 偏位, 転位, 偏位脱曰, 転位脱臼骨折に分類した（表 1 ). 本対象症
比較した.ミニプレート固定症例（4例）の平均手術時間 は131分, ラグスクリュー固定（5 例）の場合221分であっ たが, 有意差は認められなかった $(p=0.1416)$.

治癒がえられたのは保存療法症例15例中11例（73.3\%） と, 外科療法症例 13 例中 10 例 $(76.9 \%)$ であった. 治療法, 固定法, 手術時間によって, 予後に差は認められなかった （表 2 ）. また, 治療法別（外科療法群と保存療法群）に, 受 傷時年歯令骨折様式について予後の比較を行った（表 3 ). 外科療法群では, 年歯間で差は認められなかったが, 保存 療法群では年齢間で差が認められ（Kruskal-Wallis の検 定, $\mathrm{p}=0.0379)$, さらに多重比較の結果, 20 歳未満の群と 40 歳以上の群の間で有意な差があり（Mann-Whitney の U 検定, $p=0.0104), 40$ 歳以上の予後が悪いことが分かった. 同じ年齢群では外科療法群と保存療法群の間に差はなかっ た(表 $3 a$ ).

骨折様式は亀裂, 偏位骨折群と転位, 偏位脱臼, 転位脱臼 骨折群とに分類した. 外科療法群, 保存療法群ともに亀裂 骨折, 偏位骨折群の方が治癒をえる割合は多かったが, 統 計学的有意差は認めなかった. また, 同じ骨折様式群でみ ても, 治療法による有意差は検出されなかった（表 $3 \mathrm{~b}$ ).

4 ) 形態的評価

受傷後 6 か月以上経過した時点で X 線写真を撮影でき 
表 2 予後の比較

\begin{tabular}{|c|c|c|c|c|c|c|c|c|c|}
\hline \multirow[b]{2}{*}{ 分 類 } & \multirow{2}{*}{ 比較項目 } & \multirow{2}{*}{$\begin{array}{l}\text { 平均予後 } \\
\text { スコアー }\end{array}$} & \multicolumn{3}{|c|}{ 例 } & \multicolumn{2}{|l|}{ 数 } & \multirow{2}{*}{\multicolumn{2}{|c|}{ 検定結果 }} \\
\hline & & & 治癒 & 障害 I & 障害 II & 障害 III & 計 & & \\
\hline \multirow{2}{*}{ 性品 } & 男 & 3.67 & 15 & 1 & 1 & 1 & 18 & \multirow{2}{*}{\multicolumn{2}{|c|}{ NS }} \\
\hline & 女 & 3.4 & 6 & 2 & 2 & 0 & 10 & & \\
\hline \multirow{3}{*}{ 年 齢 } & 20 歳未満 & 3.82 & 10 & 0 & 1 & 0 & 11 & \multirow{3}{*}{\multicolumn{2}{|c|}{ NS }} \\
\hline & 20 歳以上 40 歳未満 & 3.63 & 7 & 0 & 0 & 1 & 8 & & \\
\hline & 40 歳以上 & 3.22 & 4 & 3 & 2 & 0 & 9 & & \\
\hline \multirow{5}{*}{ 受傷原因 } & 転 倒 & 3.5 & 5 & 2 & 1 & 0 & 8 & \multirow{5}{*}{ NS } & \\
\hline & 自転車転倒 & 3.2 & 3 & 0 & 2 & 0 & 5 & & \\
\hline & スポーツ, 暴力 & 4 & 6 & 0 & 0 & 0 & 6 & & \\
\hline & 交通事故 & 3.8 & 4 & 1 & 0 & 0 & 5 & & \\
\hline & 転落事 故 & 3.25 & 3 & 0 & 0 & 1 & 4 & & \\
\hline \multirow{2}{*}{ 骨 折 側 } & 側 & 3.77 & 15 & 0 & 2 & 0 & 17 & \multirow{2}{*}{\multicolumn{2}{|c|}{ NS }} \\
\hline & 左 側 & 3.27 & 6 & 3 & 1 & 1 & 11 & & \\
\hline \multirow{2}{*}{ 骨折部位 } & 基 底 部 & 3.73 & 9 & 1 & 1 & 0 & 11 & \multirow{2}{*}{\multicolumn{2}{|c|}{ NS }} \\
\hline & 頸 & 3.47 & 12 & 2 & 2 & 1 & 17 & & \\
\hline \multirow{2}{*}{$\begin{array}{l}\text { 他 部 位 の } \\
\text { 下顎骨骨折 }\end{array}$} & 有 & 3.63 & 7 & 0 & 0 & 1 & 8 & \multirow{2}{*}{\multicolumn{2}{|c|}{ NS }} \\
\hline & な L & 3.55 & 14 & 3 & 3 & 0 & 20 & & \\
\hline \multirow{3}{*}{ 骨折様式 } & 亀裂, 偏位, 転位 & 3.81 & 14 & 1 & 1 & 0 & 16 & \multirow{3}{*}{$* \exists \mathrm{NS}$} & \\
\hline & 偏位脱 $⿴ \zh11$ & 3.5 & 6 & 1 & 0 & 1 & 8 & & $* *$ \\
\hline & 転位脱 $⿴ \zh11$ & 2.75 & 1 & 1 & 2 & 0 & 4 & & \\
\hline \multirow{2}{*}{ 治 療 法 } & 外科療 法 & 3.54 & 10 & 0 & 3 & 0 & 13 & \multirow{2}{*}{\multicolumn{2}{|c|}{ NS }} \\
\hline & 保存療 法 & 3.6 & 11 & 3 & 0 & 1 & 15 & & \\
\hline \multirow{2}{*}{ 固 定 法 } & ラグスクリュー固定 & 3.33 & 4 & 0 & 2 & 0 & 6 & \multirow{2}{*}{\multicolumn{2}{|c|}{ NS }} \\
\hline & ミニプレート固定 & 3.71 & 6 & 0 & 1 & 0 & 7 & & \\
\hline \multirow{3}{*}{ 形態的評価 } & 完全治癒 & 3.69 & 11 & 0 & 2 & 0 & 13 & \multirow{3}{*}{\multicolumn{2}{|c|}{ NS }} \\
\hline & 不完全治癒 & 3.86 & 6 & 1 & 0 & 0 & 7 & & \\
\hline & 変形治癒 & 2.83 & 2 & 2 & 1 & 1 & 6 & & \\
\hline
\end{tabular}

調査項目で分類した各項目間で予後スコアーを用いて比較解析した. 性別, 骨折部位などのように 2 群 間での比較は Mann-Whitney U 検定を, 年齢や受傷原因のように 3 群以上の多群間比較は KruskalWallis の検定（検定結果の中括弧）をそれぞれ使用した. また, Kruskal-Wallisの検定で有意差が認め られた場合には多重比較（検定結果のカギ括弧）を Mann-Whitney U 検定で行った.

NS : no significant, $*: \mathrm{p}=0.0412, * *: \mathrm{p}=0.0106$

表 3 治療法別での比較

a. 治療法と年齢

\begin{tabular}{|c|c|c|c|c|c|c|}
\hline & & 外 科 療 法 & 保 存 & 昚 法 & & \\
\hline \multirow[b]{2}{*}{ 20歳未满 } & \multicolumn{2}{|r|}{ NS } & & \multirow[b]{2}{*}{7} & & \\
\hline & & 治瘉 3 例, 障害 II 1 例 & 治癒 7 例 & & & \\
\hline 20 歳以上 40 歳未満 & NS & 治療 4 例 & 治癒 3 例, 障害 III 1 例 & & & $* *$ \\
\hline 40歳以上 & & $\underbrace{\text { 治癒 } 3 \text { 例, 障害 II } 2 \text { 例 }}_{\mathrm{NS}}$ & 治癒 1 例, 障害 I 3 例 & - & & \\
\hline
\end{tabular}

3 群間の比較は Kruskal-Wallisの検定を使用した (中括弧)。外科療法では年齢間で有意な差は認めら れなかったが, 保存療法では年齢間で差があることがわかった $(*: \mathrm{p}=0.0379)$. 多重比較の結果（力 ギ括弧) 20 歳未満の群と 40 歳以上の群の間に有意な差があるとわかった $(* *: \mathrm{p}=0.0104)$.

NS : no significant

b. 治療法と骨折様式

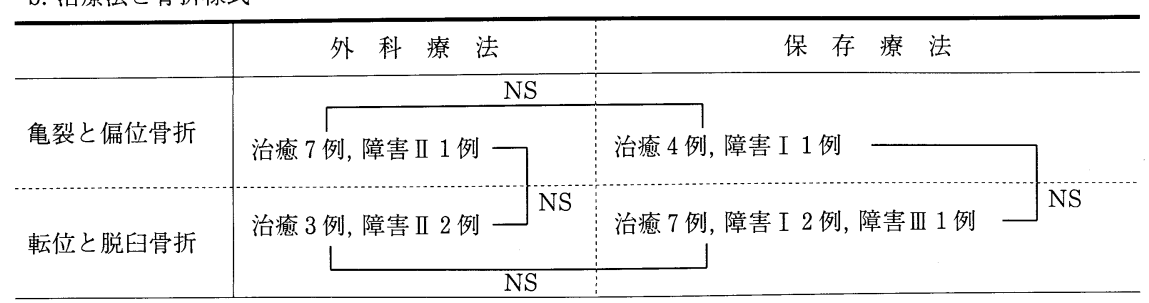

各群間で比較を行ったが,すべてにおいて有意な差は認められなかった。
た26例（保存療法症例15例，外科療法 症例11例）について, 関節突起の形態 的評価を行った。その評価は神谷ら ${ }^{2)}$ の分類に従い, 完全治癒, 不完全治癒, 変形治癒に分類した（表 1 ). その結 果, 完全治瘉は13例 $(50 \%)$, 不完全治 癒は 7 例 $(27 \%)$, 変形治癒は 6 例 $(23$ \%) であった. 外科療法症例11例中 1 例（9\%）は術後経過中に下顎頭の骨 吸収を認め変形治癒と診断された。

臨床的治癒をえた割合は完全治癒 13 例中 11 例 $(84.6 \%)$, 不完全治癒 7 例中 6 例 $(85.7 \%)$, 変形治癒 6 例中 2 例 (33.3\%) であったが, 形態的評価 の間で予後の差は認められなかった (Kruskal-Wallis の検定, $\mathrm{p}=0.0523$ ).

\section{考察}

下顎骨関節突起骨折に対する治療法 の選択基準についてはさまざまな報告 がなされており，施設により異なって いる現状である.当科においても独自 の選択基準がなく,諸家の報告 5 ，7）を 参考に行ってきた.しかし片側性骨折 に限った報告は少なく2，9），両側性関 節突起骨折は片側性骨折とは病態が全 く異なっていると考えられたため，今 回われわれは対象を片側性骨折で頸部 と基底部骨折に絞り，予後に関わる因 子を検討した。

対象症例は男女比が $1.8: 1$ で, 年齢 層も30歳未満が半数を占め, 他の報告 と同様な性別, 年齢構成であった。骨 折部位书よび骨折様式も他施設の報 告 5,7$)$ とほほ同様の結果であったが, 他部位の下顎骨骨折を認めた併発骨折 症例は 8 例 $(29 \%)$ と他施設の報告よ り少なかった. 同じ期間での片側性頭 部骨折と両側性骨折症例を合わせた場 合には，併発骨折の割合は $45 \%$ となり， 対象を限った影響と考えられた。

以上のように対象症例の極端な偏り がないなかで予後を評価したところ， 神谷ら 2)の分類で治癒をえた症例は 21例（75\%）であった.また，臨床的に はほとんど問題がないとされる障害 I 
も含めた場合は 24 例 $(85.7 \%$ ) であり，比較的良好な結果 と思われる. そのなかで, 予後に悪い影響を与えている因 子を統計学的に検討した結果, 転位脱臼の有無と受傷時年 齢であることが分かった。

そこで治療法別に骨折様式についての比較を行った。保 存療法のなかでは, 亀裂と偏位骨折群と転位と脱臼骨折群 の間に予後に大きな差は認めなかったのに対し, 外科療法 のなかでは有意差は検出されなかったものの, 後者で成績 が悪い結果であった.これは整復時の手術侵襲が逆に治癒 を阻害し, 関節機能を障害したとも考えられ，今後の検討 すべき事項であると思われた。

一方, 受傷時年齢については, 若年者の関節突起骨折で 成績が良好という他家の報告 $5 ， 7 ， 8 ， 10)$ に一致し，20歳未 満の群では11例中10例（90.9\%）が治癒をえていた. 治療 法別に検討したところ, 保存療法群で年齢間（20歳未満の 群と40歳以上の群) に有意差が検出され, 骨の成長やリモ デリングが活発な時期においての保存療法は優れていると 考えられた。

外科療法群で治癒をえられなかったのは 3 例しかなく， 治癒をえた群とえられなかった群の間で比較解析はできな かったしかし，治癒をえられなかった 3 例のうち， 2 例が 転位脱臼骨折であった。手術侵襲を考えた場合, 転位骨折 や脱臼骨折では, 整復を行うための骨片周囲組織の剥離範 囲は必然的に広くなり，周囲からの栄養がそしくなると考 えられる.ミニプレート固定では骨面に対して直角にスク リューを入れるため, 周囲組織への侵襲はより大きくなる. 一方，ラグスクリュー固定 $\left.{ }^{9}\right)$ は骨髄内を貫通させるため， さらに骨折片や関節に対する栄養路が減少され，術後の関 節機能に与える障害は多くなると推察される。このように 外科療法は受傷時の関節への侵襲の他に, 手術侵襲も加わ ることを十分考慮する必要があると考えられた．

そこで本疾患に対する治療法の選択基準を考えた場合， 20歳未満では保存療法が全例において治癒をえていること から，20歳未満では保存療法を選択する方が望ましいと思 われた. 20 歳未満で治癒をえられなかった 1 例は, 転位脱 白骨折で外科療法を選択した症例であった。骨のリモデリ ングや周囲組織の治癒が活発な年齢条件であるにも関わら ず，その予後は障害 IIであった. 受傷時の衝撃, 手術時の侵 襲が大きかったか, 術後の顎運動療法に何か問題があった のかと考えられる. 20歳以上40歳未満では外科療法が全例 において治癒をえているが, 同じ年齢群で保存療法との間 に有意差は認められず, 外科療法が優れているとはいえな かった. 保存療法のなかで40歳以上の群は20歳未満の群と 比較すると明らかに治癒がえられにくい結果であった。 40 歳以上の外科療法群も決して良好な成績とはいえないが, 基底部骨折で骨片の偏位が小さい症例は治癒をえており，
このような症例は40歳以上でも外科療法が望ましいと考え られた. すなわち, 手術侵襲からの回復が低年齢群より劣 ることを考慮し, 手術侵襲が少ないと想定される症例が適 応であると考えられた。

開口量を主として予後評価を行った今回の検討では，片 側性関節突起骨折の場合, 絶対的な手術適応とする基準は 導けなかった. しかし, 予後評価で開口時の下顎偏位量を 測定した神谷ら ${ }^{2)}$ の報告では, 外科療法が保存療法に比べ てその偏位量が少なく, 審美的にも優れているという結論 であった. 治療法の明確な選択基準を考えた場合, 多角的 な調査の他, 今後さらに症例を加えて検討する必要がある と考えられた。

\section{結語}

今回われわれは片側性下顎骨関節突起頸部および基底部 骨折症例28例の予後を調査し, 骨折様式が転位脱臼骨折で あることと, 受傷時年歯が40歳以上であることが予後不良 の一因となることを統計学的に明らかにした。

本論文の内容の一部は第13回日本口腔科学会近畿地方部会 (2001年12月, 西宮市)において口演発表した。 謝辞

本研究の遂行にあたり, 統計学的解析について御指導頂い た徳島文理大学人間生活学部教授古本奈奈代先生に深謝致し ます。

\section{引用文 献}

1) Thoma, K.H.: Oral Surgery. 5th ed. Mosby Co, St Louis, 1969, p572.

2）神谷祐司, 日下雅裕, 他：下顎骨関節突起骨折にお けるキルシュナー鋼線使用症例の予後について.日 口外誌 37: 1165-1172 1991.

3) Maclennan, W.D.: Consideration of 180 cases of typical fractures of the mandibular condylar process. Brit J Plast Surg 5: 122-132 1952.

4) Archer, W.H.: A step by step of operative techniques; Oral Surgery. 4th ed. W.B. Saunders Co. Philadelphia \& London, 1966, p833.

5）森永宏喜, 木野孔司, 他：過去 12 年間の当科におけ る下䫟骨関節突起骨折の臨床統計的観察. 日口外誌 36: 2055-2068 1990.

6）市川健司, 大多和亜紀, 他: 顎関節突起骨折に対す る非観血的治療の有用性の検討. 日口外誌 42: 5815861996.

7）森本佳成, 瀧岡 渡, 他：関節突起骨折に対する治 療法の適応に関する検討。日口外誌 45: 677-684 1999.

8）久保四郎, 村橋 譲, 他 : 顎関節突起骨折 124 症例に 関する臨床的検討. 特にその分類について. 日口外 誌 29: 1794-1805 1983 .

9）飯田征二, 西村則彦, 他 : ラグスクリューシステム （Martin-Eckelt）を用いた顎関節突起骨折の治療 経験. 日口外誌 43: 927-929 1997.

10）佐々木 勲, 佐々木 朗, 他: 顎関節突起骨折の臨 床的観察. 日口外誌 37: 447-455 1991. 